\title{
Wound Healing Effect of Satureja Khuzistanica and Satureja Rechingeri Ethanolic Extracts in NMRI Adult Mice
}

\author{
Halimeh Sahraei, ${ }^{1}$ Ahmad Gharzi, ${ }^{1}$ Hamza Amiri, ${ }^{1}$ Mohsen Abbasi, ${ }^{2}$ and Mohammadreza Gholami ${ }^{3,}$ \\ ${ }^{1}$ Department of Biology, Lorestan University, Khorramabad, IR Iran \\ ${ }^{2}$ Department of Veterinary, Lorestan University, Khorramabad, IR Iran \\ ${ }^{3}$ Razi Herbal Medicine Research Center, Lorestan University of Medical Sciences, Khorramabad, IR Iran \\ "Corresponding author: Mohammadreza Gholami, Razi Herbal Medicine Research Center, Lorestan University of Medical Sciences, Khorramabad, IR Iran. E-mail: \\ gholami.mr@lums.ac.ir
}

Received 2015 January 23; Accepted 2015 July 5.

\begin{abstract}
Background: Scientists are trying to find ways for skin wound healing. The potential role of plants on wound healing is of interest and controversial.

Objectives: In this study, the effects of topical application of Satureja Khuzestanica and Satureja Rechingeri methanolic extract on skin wound healing in mice has been evaluated. Satureja Khuzestanica and satureja Rechingeri has anti-oxidant and anti-inflammatory properties and may enhance wound healing process.

Materials and Methods: For this experimental study, 48 healthy male mice were randomly designated to four groups of A, B, C and D which, respectively treated with, Satureja Khuzestanica extract, and satureja Rechingeri extract, methanol $98 \%$ for 22 days. Circular wounds were made in three layers of skin with $10 \mathrm{~mm}$ diameter in all three layers (dermis, epidermis, and hypodermis). Specimens were taken at 3 rd day, $^{\text {th }}$ day, $14^{\text {st }}$ day and $22^{\text {th }}$ day for microscopic examinations.

Results: Compare H and E staining sections in the study groups showed that Satureja Rechingeri treated group has best effect on the wound healing in the comparison with placebo at $7^{\text {th }}$ day, $14^{\text {st }}$ day and don't ameliorate wound at $22^{\text {th }}$ day of treatment.

Conclusions: The results showed that Satureja Khuzestanica extract not suitable for wound healing. Satureja Rechingeri extract the fourteenth day is appropriate for healing and this plant has been limited period.
\end{abstract}

Keywords: Healing Process, Surgical Wound, Mice, Satureja Khuzestanica, Satureja Rechingeri

\section{Background}

The wound is gap or discontinuity in the epidermis or dermis that occurred following a traumatic or pathological changes in the skin or body [1]. Skin ulcers, caused by different reasons and divided into different types. Wound classification based on depth is divided into two types: The superficial and deep wound. Another classification is based on the length of wound that divided into two, acute and chronic wounds groups [2-5]. Wound healing is the most important biological processes, including repair and production of new tissue [6]. It's activated a cellular response and contains a complex pathophysiological process including several cellular and biological sub processes, e.g. inflammation, angiogenesis, and collagen confession [7]. Angiogenesis is a landmark of wound healing that provides oxygen, nutrients, and blood-borne cells to the site of tissue injury. In inflammation phase, the vessels constrict and platelets activate the coagulation and fibrin following its creation. Macrophages are important cells in the inflammatory phase which stimulates wound healing. Inflammation phase started at the third day af- ter injury and the maximum of damage observed at the third week. Collagen confession phase begins immediately and lasts for months. In this phase, collagen synthesis begins by fibroblasts and done stimulation of macrophages [8-12]. Inflammation maintenance and scarce vessel formation comprise the most noticeable causes of delayed wound healing [13]. On the other hand, wound fibrosis or anomalous increase of collagen in the wound that lead to an unpleasant scar [14]. Recent research has shown that several combinations are used for wound healing such as Acetic acid, Hydrogen peroxide [15]. Common plant extracts, e.g. Grape seed, Lemon, Rosemary, and Jojoba, have been employed for wound healing and longevity increase. All of these plants have a communal property, e.g. producing combinations with phenolic structure [16]. These phytochemicals ordinarily respond with some combinations such as oxygen free radicals and other macromolecules in order to neutralize free radicals and initiate biological special effects [16].

Medicinal plants have been used traditionally in the treatment of disease. Satureja Khuzestanica is established antioxidants that used in medicinal plants. Satureja khuzis- 
tanica belonging to the dark one native plants of lamiaceae and is widely grown in the southern part of Iran [17]. Carvacrol is one of the most important compounds Satureja Khuzestanica. Carvacrol is a wide spectrum of antimicrobial activities against bacteria. When bacteria are exposed to carvacrol, ATP, and intracellular potassium leak from the cell membrane and the bacterial cell dies [18]. Carvacrol is insoluble in water and soluble in alcohol and ether and properties anti-inflammatory, analgesic and anti-microbial [19]. Satureja Khuzistanica is utilizing for its anti-oxidant, anti-lipid, anti-inflammatory, and antibacterial effects and might similarly play a role in preventing intra-abdominal adhesion. The major of these properties could be attributed to the plant's polyphenol, in particular, catechin combinations [20-24]. Anti-oxidant combinations of Satureja Khuzestanica could increase collagen dimensions and hence heal the wounds [25]. These combinations (e.g. epigallocatechin gallate) have also been used as a cause for keratinocytes reproduction and distinction [26]. Also, its anti-fibrogen effects have been established in some animal models [27]. Satureja Rechingeri (Labiatae) is described as a new species from Iran, and its relationship to S. khuzistanica. Satureja rechingeri is belongs to the Lamiaceae family, perennial plant and very aromatic, with wooden base, the branching base, stem is completely covered with long trichomes, basal leaf is circular. The upper leaves are gradually toward the top of the folded side. The chemical composition of the essential oil is carvacrol [28]. Taken to gather, Satureja Khuzistanica and Satureja Rechingeri have anti-oxidant and anti-inflammatory properties and may enhance wound healing process.

\section{Objectives}

The main goal of the present study was to examine effect of ethanolic extract of Satureja Khuzestanica and Satureja Rechingeri on postsurgical wound healing process.

\section{Materials and Methods}

All experiments were performed in agreement with principles of laboratory animal care. Male mouse were obtained from Razi herbal medicine research center. Mice were euthanized by excessive doses of ketamine $\mathrm{HCl}$ (50 $\mathrm{mg} / \mathrm{kg}$ ) and xylazine $(5 \mathrm{mg} / \mathrm{kg}$ ) (Pharmacia and Upiohn, Erlangen, Germany) [29] in accordance with the protocols approved by the Lorestan University Animal Care and use committee. Every attempt was made to minimize the number of animals used and their pain.

\subsection{Extract Preparation}

Maceration method was employed to make the extract. For this purpose, $700 \mathrm{~g}$ Satureja Khuzestanica and $700 \mathrm{~g}$ Satureja Rechingeri was transported into an Erlenmeyer, 1 Liter methanol 98\% (Nasr Co. Iran) was added and the solution was left at laboratory temperature. Forty eight hours later, the extract was filtrated through a filter paper and the grind was squeezed to discharge. Finally, the extract was concentrated by rotary evaporator [30].

\subsection{Animals and Study Design}

In this experimental study 80 male NMRI mice weighing 25 - $30 \mathrm{~g}$ were used. They were randomly divided into four groups ( $\mathrm{N}=20$ per group). The animals were acclimatized for one week to the condition of our laboratory before the commencement of the experiment. The animals were exposed to 12 hours light and 12 hours dark cycle at a room temperature of $22^{\circ} \mathrm{C}$. The animals had free access to standard laboratory chow and water ad libitum. The studies were performed during the same time in all groups. The rats were grouped as follows:

Group 1: control group (without surgery),

Group 2: placebo group,

Group 3: Satureja Khuzestanica-treated group,

Group 4: Satureja Rechingeri-treated group.

The rats were anesthetized once intraperitoneally with ketamine $\mathrm{HCl}(50 \mathrm{mg} / \mathrm{kg}$ ) and xylazine (5 mg/kg) [10] in accordance with the protocol approved by the animal care and use committee and prepared for surgery. Circular wounds were made in three layers of skin with $10 \mathrm{~mm}$ diameter in all three layers (dermis, epidermis, and hypodermis). Specimens were taken at $3^{\text {rd }}$ day, $7^{\text {th }}$ day, $14^{\text {st }}$ day, and $22^{\text {th }}$ day for microscopic examinations. Sham group received ethanolic extract. Satureja Khuzestanica-treated group and Satureja Rechingeri-treated group received daily topical applications of traditional Satureja Rechingeri (1 g/day) and Satureja Khuzestanica (1 g/day). On the $3^{\text {th }}, 7^{\text {th }}$, $14^{\text {th }}$, and $22^{\text {th }}$ days of operation, five mice separate from each group and subsequently a segment of treated skin was removed and fixed with $10 \%$ formalin solution. Specimens embedded in paraffin after fixation, dehydration, clearing and infiltration. The paraffin tissue blocks were cut with a microtome at $5 \mu \mathrm{m}$, stained with hematoxylin and eosin (H\&E). Sections studied according Asadi et al. [31], method's included;1) epithelial regeneration; 2) granulation tissue thickness, 3) angiogenesis assessment of wound site for the rank of healing. 2.10. Data analysis. Data analysis was performed by SPSS 16, Kruskal-Wallis and Friedman test (for histopathology analysis). Sig $<0.05$ was considered as statistically significant. 


\section{Results}

Microscopic features of wounds on day 3: Compare $\mathrm{H}$ and E staining sections in the study groups showed that Satureja Rechingeri treated group and Satureja Khuzistanica treated group haven't effect on the wound healing in the comparison with placebo (Figure 1). Study epithelial regeneration, granulation, and angiogenesis in the sections tissue on day 3 of Satureja Khuzistanica group than sham group and Satureja Rechingeri group (Figure 1).

Microscopic features of wounds on day 7: Compare $\mathrm{H}$ and E staining sections in the study groups showed that Satureja Rechingeri treated group has best effect on the wound healing in the comparison with placebo and Satureja Khuzistanica treated group (Figure 1). Satureja Rechingeri ethanolic extract can decrease granulation, increase epithelial regeneration, and angiogenesis. Satureja khuzistanica ethanolic extract can increase granulation, epithelial regeneration, and angiogenesis (Figure 1).

Microscopic features of wounds on day 14: Compare $\mathrm{H}$ and E staining sections in the study groups showed that Satureja Rechingeri treated group has best effect on the wound healing in the comparison with placebo and Satureja Khuzistanica treated group (Figure 1).

Table 1. System for Scoring the Histological Features of wound tissue Samples

\begin{tabular}{|c|c|c|c|}
\hline Score & $\begin{array}{c}\text { Epithelial } \\
\text { Regeneration }\end{array}$ & $\begin{array}{c}\text { Granulation } \\
\text { Tissue Thickness }\end{array}$ & Angiogenesis \\
\hline $\mathbf{1}$ & $\begin{array}{l}\text { Little epithelial } \\
\text { organization }\end{array}$ & Thin granular layer & $\begin{array}{c}\text { Altered } \\
\text { angiogenesis (1-2 } \\
\text { vessels per site) }\end{array}$ \\
\hline 2 & $\begin{array}{l}\text { Moderate epithelial } \\
\text { organization }\end{array}$ & $\begin{array}{l}\text { Moderate granular } \\
\text { layer }\end{array}$ & $\begin{array}{c}\text { Few newly formed } \\
\text { capillary vessels (3- } \\
6 \text { vessels per site) }\end{array}$ \\
\hline 3 & $\begin{array}{l}\text { Complete epithelial } \\
\text { organization }\end{array}$ & thick granular layer & $\begin{array}{c}\text { Newly formed } \\
\text { capillary vessels (7- } \\
10 \text { vessels per site) }\end{array}$ \\
\hline 4 & $\begin{array}{l}\text { Complete epithelial } \\
\text { organization }\end{array}$ & $\begin{array}{l}\text { Very thick granular } \\
\text { layer }\end{array}$ & $\begin{array}{l}\text { Newly formed and } \\
\text { well-structured } \\
\text { capillary vessels (> } \\
10 \text { vessels per site) }\end{array}$ \\
\hline
\end{tabular}

Satureja Rechingeri ethanolic extract can decrease granulation and angiogenesis and increase epithelial regeneration. Satureja khuzistanica ethanolic extract can decrease granulation and angiogenesis and increase epithelial regeneration (Figures 1 and 3).

Microscopic features of wounds on day 22: Compare $\mathrm{H}$ and E staining sections in the study groups showed that Satureja Rechingeri treated group and Satureja Khuzistanica treated group haven't effect on the wound healing in the comparison with placebo (Figure 1). Satureja Rechingeri ethanolic extract can increase granulation and angiogen- esis and decrease epithelial regeneration. Satureja khuzistanica ethanolic extract can increase granulation and angiogenesis and decrease epithelial regeneration (Figure 1).

\section{Discussion}

Wound healing is a complex process of rehabilitate cellular structures and tissue layers in injured tissue [7]. Wound healing include of different phases such as contraction, granulation, epithelization and collagenation [32,33]. Research showed that wound healing involved in three phases: inflammation, proliferation, and tissue remodeling with scar formation. The inflammatory phase is described by hemostasis and swelling. Proliferative phase is result from by epithelialization, angiogenesis, and collagen confession. In the maturation phase, the wound undergoes act of contracting resulting in a smaller amount of apparent mark with a scar tissue [34]. Granulation tissue which is creating in the final part of the proliferative phase is primarily composed of fibroblasts, collagen, and recently small blood vessels [35]. Several effects of Satureja Khuzestanica and its compounds have been already examined, indicating that this plant, in traditional medicine, has medical uses including, antibacterial, antiinflammatory, and antioxidant. In a study that showed vitamin C in addition to Satureja Khuzestanica is effective in preventing abdominal adhesions during the adhesions process [36]. Also, research has shown that Satureja Khuzestanica is effective in preventing atherosclerosis, atherosclerosis is a direct correlation with angiogenesis, that the present study is approving $[36,37]$. Therefore probably Satureja Khuzistanica with high antioxidant property cannot be useful in wound healing. The high granulation at the last days indicates that the wound isn't healing yet and healing process is delayed or wound healing mechanism at the granulation process is stopped. The high angiogenesis at the last days indicates that the wound isn't healing yet and healing process is delayed, because the epidermis Satureja Rechingeri scores lower than the control group confirmation of the delay caused by this medicine plant [38]. Microscopic observations indicated that the formation of a large scar in Satureja Rechingeri treated group than the control group, causing severe adhesion to the surrounding tissues and create a barrier to the migration of epithelial cells and the resulting delay repair of satureja rechingeri treated group compared to the control group. Satureja Rechingeri may also prevent the wound from being wettish which is suitable for regeneration [39]. Despite the active ingredient antioxidants in plant Satureja Khuzestanica, the results indicate inadequate effect of ethanol extract of this plant in wound healing. Therefore, due to the inefficiency of the ethanol extract of leaves Satureja Khuzestanica healing, its 


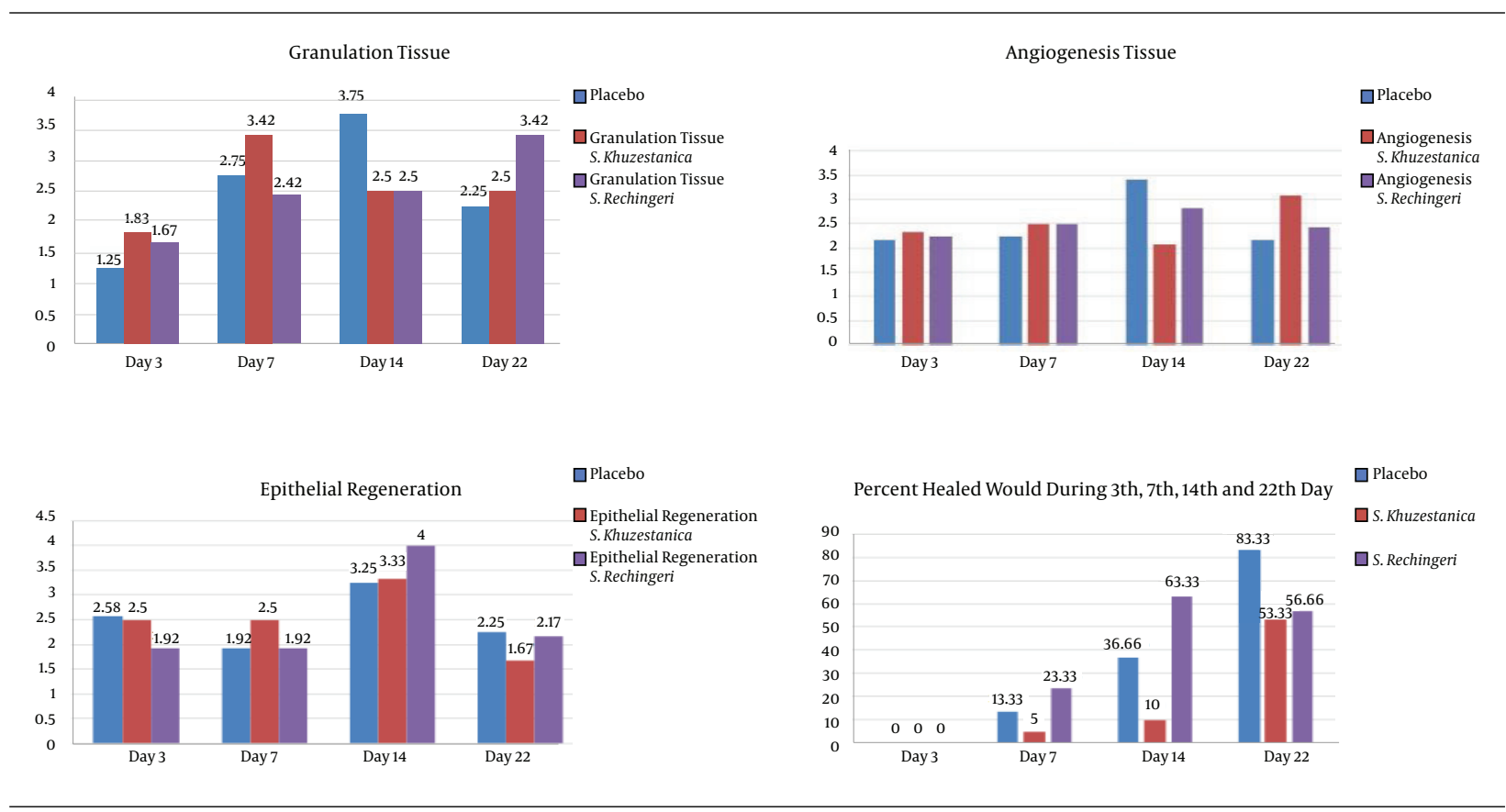

Figure 1. Percent Healed Wound in the Three Treatment Groups During Different Days and Histological Features of the Wound Tissue Samples

Figure 2. Pictures A, B and C Shows Satureja Khuzistanica Treatment Group on day 22 and Pictures D, E and F Shows Satureja Rechingeri Treatment Group on Day 22
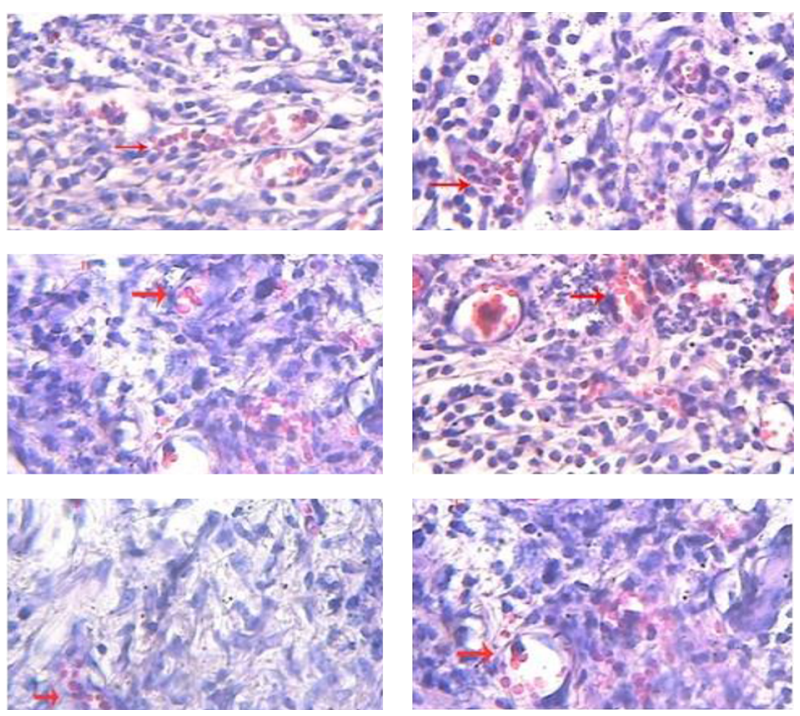

Dense angiogenesis (arrows) was present in dermis. (H\&E staining) $(\times 400)$

use as a medicinal plant used in traditional medicine and is not recommended. As regards Satureja Rechingeri plant until the fourteenth day will be healing, probably, a short treatment period and should be used only for a specified period and for the better performance is recommended
Figure 3. Pictures D, E and F Shows Satureja Rechingeri Treatment Group on Day 22 and Pictures A, B and C Shows Satureja Khuzistanica Treatment Group on Day 22
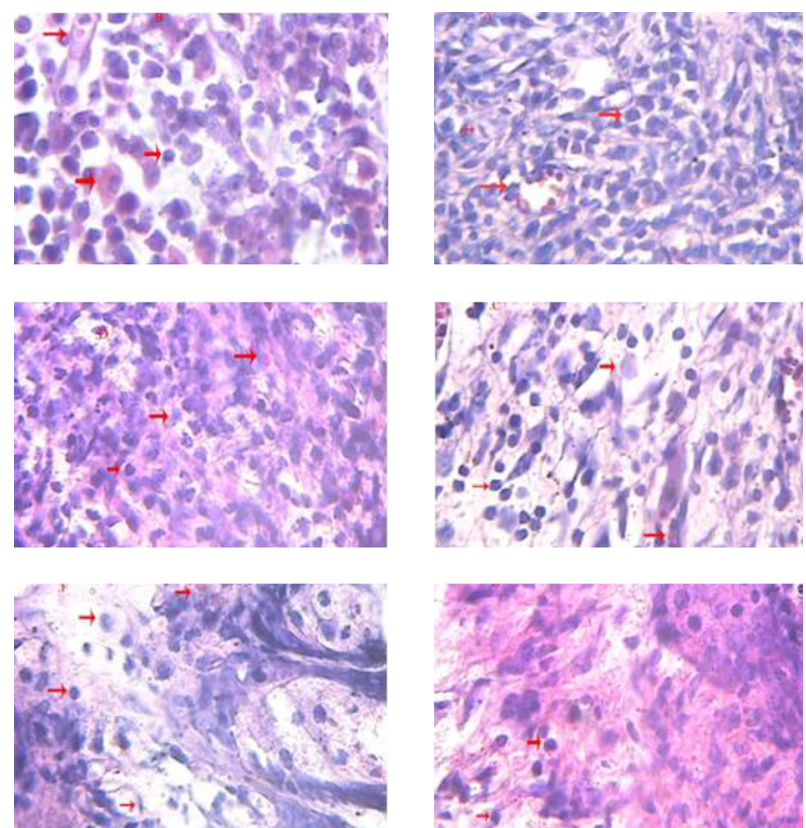

Dense granulation (arrows) was present in dermis. (H\&E staining) $(\times 400)$.

use with humid bandage and this needs to be investigated further. 
Figure 4. In the Picture A and B Shows Lack of Skin Epithelial Tissue Layers in Group A (Satureja Khuzestanica,) of Day 22, While Picture C, D, E, F Shows the Complete Formation of the Epidermis and Dermis Layers is Clearly Visible Tissue Specimen Taken From Group B (Satureja Rechingeri) of Day 14 and Picture J, L Lack of Skin Epithelial Tissue Layers in Group B (Satureja Rechingeri) of Day 22
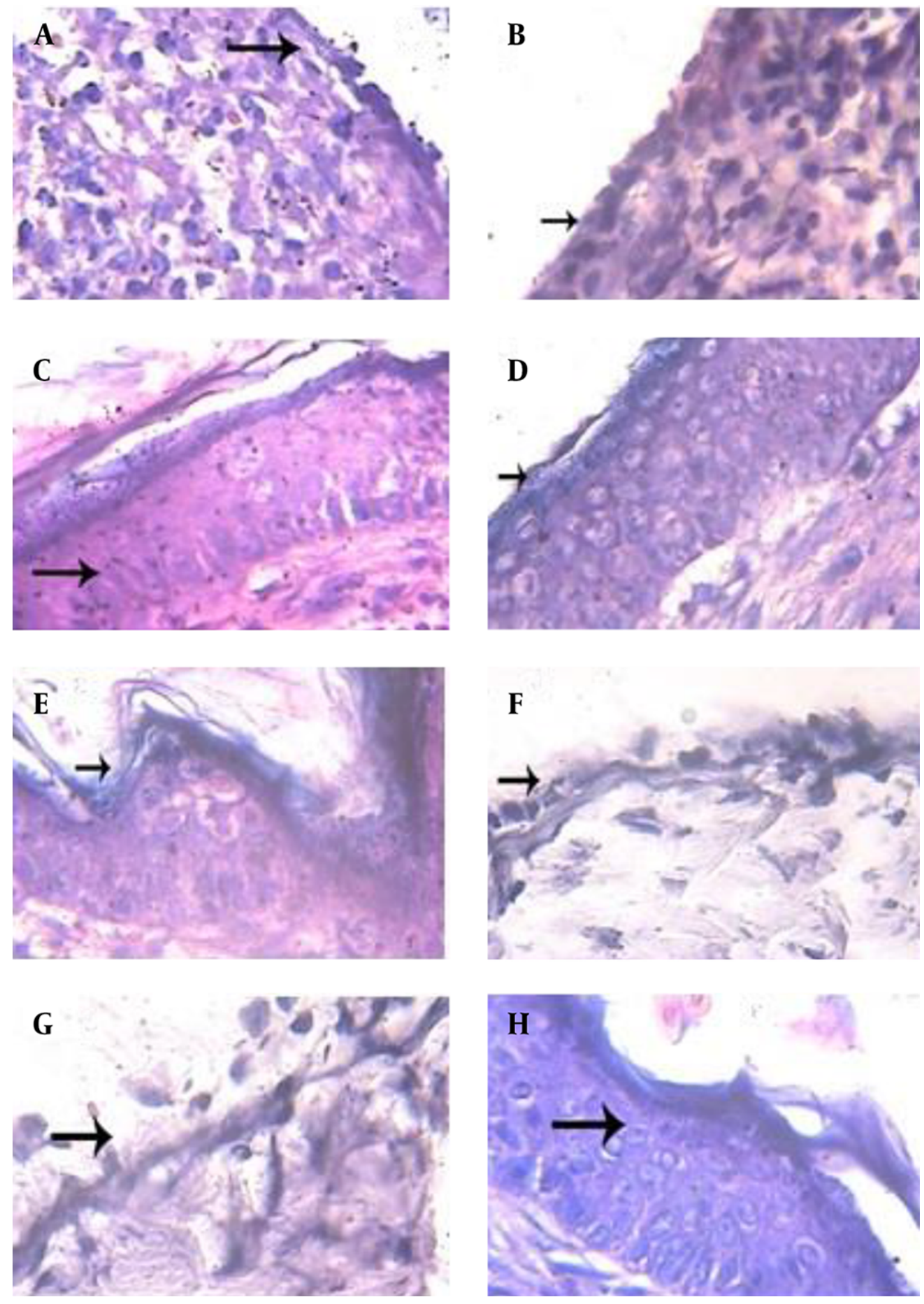

$($ H\&E staining $)(\times 400)$. 


\section{Acknowledgments}

The authors thank the head and staff of Razi herbal medicine research center of Lorestan Medical University. Special thank from Zahra Khanipour.

\section{Footnotes}

Authors' Contribution All authors declare that they have no conflict of interest.

Funding/Support Lorestan University of Medical Sciences, Khorramabad.

\section{References}

1. Prasad V, Dorle AK. Evaluation of ghee based formulation for wound healing activity. J Ethnopharmacol. 2006;107(1):38-47. doi: 10.1016/j.jep.2006.02.006. [PubMed:16546334].

2. Asadi SY, Zamiri A, Ezzati S. Effect of alcoholic extract of green tea (Camellia sinensis) on the healing process in surgical and burn wounds in rats [in Persian]. J Birjand Uni Med Sci. 2011;18(1):1-9.

3. Golboe H, Ghaderi R. Letter to editor: Wound healing [in Persian].J Birjand Uni Med Sci. 2012;19(3):344-6.

4. Prado RP, Garcia SB, Thomazini JA, Piccinato CE. Effects of 830 and 670 $\mathrm{nm}$ laser on viability of random skin flap in rats. Photomed Laser Surg. 2012;30(8):418-24. doi: 10.1089/pho.2011.3042. [PubMed: 22730913].

5. Dargaville TR, Farrugia BL, Broadbent JA, Pace S, Upton Z, Voelcker NH. Sensors and imaging for wound healing: a review. Biosens Bioelectron. 2013;41:30-42. doi: 10.1016/j.bios.2012.09.029. [PubMed: 23058663].

6. Thomas JC. Veterinary pathology. 6 ed. USA: William's and Wilkins; 1997. pp. 150-6.

7. Desmouliere A, Redard M, Darby I. Apoptosis mediates the decrease in cellularity during the transition between granulation tissue and scar. Am J Pathol. 1995;146(1):56-66.

8. Levine SM, Sinno S, Levine JP, Saadeh PB. An evidence-based approach to the surgical management of pressure ulcers. Ann Plast Surg. 2012;69(4):482-4. doi: 10.1097/SAP.0b013e31824b26bc. [PubMed: 22868322].

9. Cooper R, Jenkins R. Are there feasible prospects for manuka honey as an alternative to conventional antimicrobials?. Expert Rev Anti Infect Ther. 2012;10(6):623-5. doi: 10.1586/eri.12.46. [PubMed: 22734952].

10. Morton LM, Phillips TJ. Wound healing update. Semin Cutan Med Surg. 2012;31(1):33-7. doi: 10.1016/j.sder.2011.11.007. [PubMed: 22361287].

11. Ghaderi R, Zardast M, Hosseini M. Comparison of antibacterial effect of cichorium intybus 1 . With vancomycin, ceftriaxone, ciprofloxacin and penicillin (in vitro). Clin Exp Pharmacol. 2012;2(2)::2(2):10001-13.

12. Campbell RM, Perlis CS, Fisher E, Gloster HJ. Gentamicin ointment versus petrolatum for management of auricular wounds. Dermatol Surg. 2005;31(6):664-9. [PubMed:15996417].

13. Appleton I. Wound healing: Future directions. J Drugs. 2003;6(11):1067-72.

14. Norrby K. Angiogenesis: new aspects relating to its initiation and control. Acta Pathologica Microbiologica Immunologica Scandinavica. 1997;105(6):417-37.

15. Life Extension Foundation. Wound healing (surgical wound, trauma, burns ) 2000. Available from: www.lef.org/protocols/abstracts/abstr$111 \mathrm{c}$.

16. Hsu S. Green tea and the skin. JAm Acad Dermatol. 2005;52(6):1049-59. doi:10.1016/j.jaad.2004.12.044. [PubMed:15928624].

17. Nazari A, Delfan B, Shirkhani Y. Effete of detection of Satureja khuzestanica Jamzad on blood coagulation time, triglyceri and glucose levels in rats. Pak J Biological Sci. 2005;8(6):790-1. doi: 10.3923/pjbs.2005.790.792.
18. Leyer GJ, Johnson EA. Acid adaptation induces cross-protection against environmental stresses in Salmonella typhimurium. Appl Environ Microbiol. 1993;59(6):1842-7. [PubMed: 8328803].

19. Quintans-Junior LG, Guimaraes A, Araujo BE. Carvacrol, (-)-borneol and citral reduce convulsant activity in rodents. African J Biotechnol 2010;9(39):6566-72.

20. Katiyar SK, Afaq F, Perez A. Green tea polyphenol epigallocatechin 3-gallate treatment of human skin inhibits ultraviolet radiationinduced oxidative stress. Carcinogenesis. 2001;22(2):287-94.

21. Katiyar SK, Elmets CA. Green tea polyphenolic antioxidants and skin photoprotection (Review). Int J Oncol. 2001;18(6):1307-13. [PubMed: 11351267].

22. Chan MMY, Dunne F, Ho C. T. . Inhibition of inducible nitric oxide synthase gene expression and enzyme activity by epigallocatechin gallate, a natural product from green tea. Biochem Pharmacol. 1997;54(12):1281-6.

23. Yen GC, Chen HY. Scavenging effect of various tea extracts on superoxide derived from the metabolism of mutagens. Biosci Biotechno Biochem. 1998;62(9):1768-70. [PubMed: 9805379].

24. Frei B, Higdon JV. Antioxidant activity of tea polyphenols in vivo: evidence from animal studies. J Nutr. 2003;133(10):3275S-84S. [PubMed: 14519826].

25. Abdollahi M, Salehnia A, Mortazavi S. Antioxidant, antidiabetic, antihyperlipidemic, reproduction stimulatory properties, and safety of essential oil of Satureja khuzestanica in rat in vivo: An oxicopharmacological study. Med Sci Monit. 2003;9(9):331-5.

26. Hsu S, Bollag WB, Lewis J. Green tea polyphenols induce differentiation and proliferation in epidermal keratinocytes. J Pharmacol Exp Ther. 2003;306(1):29-34.

27. Nakamuta M, Higashi N, Kohjima M, Fukushima M, Ohta S, Kotoh K, et al. Epigallocatechin-3-gallate, a polyphenol component of green tea, suppresses both collagen production and collagenase activity in hepatic stellate cells. Int JMol Med. 2005;16(4):677-81.[PubMed:16142404]

28. Jamzad Z. Satureja rechingeri (Labiatae)-a new species from Iran. Ann Naturhist Mus Wien. 1996;98:75-7.

29. Hemadi M, Zargar M, Sobhani A, Sobhani A. Assessment of morphological and functional changes in neonate vitrified testis grafts after host treatment with melatonin. Folia Morphol (Warsz). 2011;70(2):95102. [PubMed: 21630230].

30. Khalaji N, Neyestani T. The inhibitory effects of black and green teas (Camellia sinensis) on growth of pathogenic Escherichia coli, in vitro. Iran J Nutr Sci. 2007;1(3):33-8.

31. Asadi SY, Parsaei P, Karimi M, Ezzati S, Zamiri A, Mohammadizadeh $\mathrm{F}$, et al. Effect of green tea (Camellia sinensis) extract on healing process of surgical wounds in rat. Int J Surg. 2013;11(4):332-7. doi: 10.1016/j.ijsu.2013.02.014. [PubMed: 23459184].

32. Ayyanar M, Ignacimuthu S. Herbal medicines for wound healing among tribal people in Southern India, ethnobotanical and scientific evidences. Int J Appl Res Nat Prod. 2009; 2:.;2:29-42.

33. Wild T, Rahbarnia A, Kellner M, Sobotka L, Eberlein T. Basics in nutrition and wound healing. Nutrition. 2010;26(9):862-6. doi 10.1016/j.nut.2010.05.008. [PubMed: 20692599].

34. Phillips GD, Whitehead RA, Knighton DR. Initiation and pattern of angiogenesis in wound healing in the rat. Am J Anat. 1991;192(3):257-62 doi: 10.1002/aja.1001920305. [PubMed: 1722074].

35. Richard V. [Community financing for health care in Africa: mutual health insurance]. Med Trop (Mars). 2005;65(1):87-90. [PubMed: 15903084].

36. Najafian A, Yosefzadi M, Alavi A. Post surgical adhesion prevention Vitamin C or Satureja Khuzestanica.J Veter Clin Pathol. 2013;8(6):178692.

37. Vila V, Martinez-Sales V, Almenar L, Lazaro IS, Villa P, Reganon E. Inflammation, endothelial dysfunction and angiogenesis markers in chronic heart failure patients. Int J Cardiol. 2008;130(2):276-7. doi 10.1016/j.ijcard.2007.07.010. [PubMed: 17727986]. 
38. Clark RA. Biology of dermal wound repair. Dermatol Clin. 1993;11(4):647-66. [PubMed: 8222349].

39. Subrahmanyam M. A prospective randomized clinical and histolog- ical study of superficial burn wound with honeyand silver sulfadiazine. J Obstetric Gyneocol Br Comonw. 1970;77(11):1037-40. 